\title{
Health promotion actions in the School Health Program in Ceará: nursing contributions
}

\author{
Ações de promoção da saúde no Programa Saúde na Escola no Ceará: contribuições da enfermagem \\ Acciones de promoción de la salud en el Programa de Salud en la Escuela de Ceará: aportes de enfermería
}

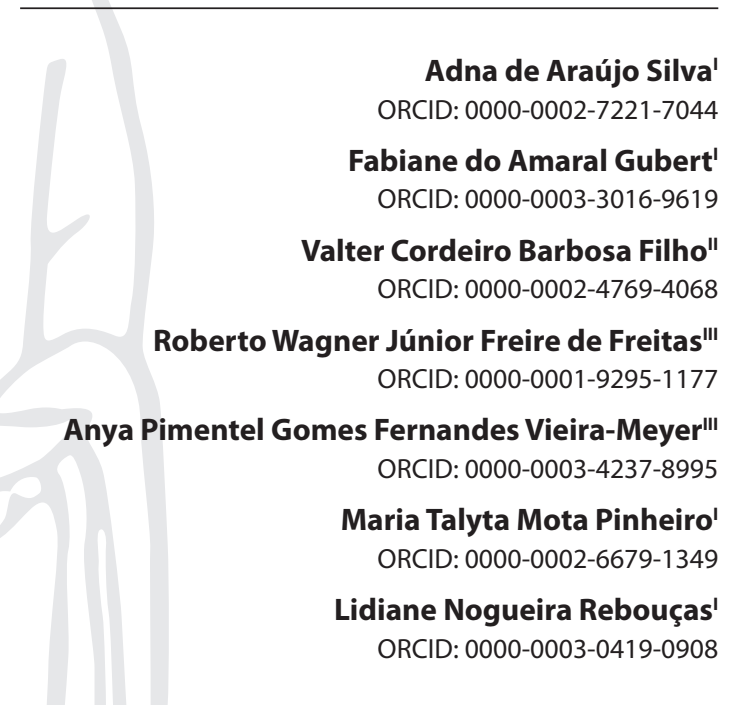

'Universidade Federal do Ceará. Fortaleza, Ceará, Brazil. "Instituto Federal de Educação, Ciência e Tecnologia do Ceará. Aracati, Ceará, Brazil.

"'Fundação Oswaldo Cruz. Fortaleza, Ceará, Brazil.

How to cite this article: Silva AA, Gubert FA, Barbosa Filho VC, Freitas RWJF, Vieira-Meyer APGF, Pinheiro MTM, et al. Health promotion actions in the School Health Program in Ceará: nursing contributions. Rev Bras Enferm. 2021;74(1):e20190769. doi: http://dx.doi.org/10.1590/0034-7167-2019-0769

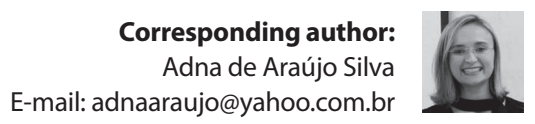

EDITOR IN CHIEF: Antonio José de Almeida Filho ASSOCIATE EDITOR: Hugo Fernandes

Submission: $03-31-2020$

Approval: 09-09-2020

\section{ABSTRACT}

Objectives: to compare health promotion actions carried out by Family Health teams in Ceará, linked to the School Health Program. Methods: a cross-sectional study involving the first and second cycles of an external assessment of 910 and 1,626 teams from 184 municipalities, which joined the Brazilian National Program for Improvement of Access and Quality of Primary Care. Eight clinical assessment and seven health promotion indicators were assessed, together with health professionals working in schools. Results: the interviewees were nurses (95.6\% and 98.3\%). Between the cycles, there was an increase in clinical assessment $(78.7 \%$ and $91.3 \%)$, health promotion and disease prevention (82.5\% and $89.3 \%)$ and survey of students for follow-up (41.4\% and $66.4 \%$ ) in schools. Conclusions: health actions at school advanced between cycles, with nurses as protagonists in school health, which can reduce vulnerabilities in children and adolescents and qualify Primary Care.

Descriptors: Nursing; Health Promotion; Disease Prevention; Family Health Strategy; School Health Services.

\section{RESUMO}

Objetivos: comparar as ações de promoção da saúde realizadas pelas equipes de Saúde da Família do Ceará vinculadas ao Programa Saúde na Escola. Métodos: estudo transversal, envolvendo os primeiros e segundos ciclos da avaliação externa de 910 e 1.626 equipes, respectivamente, de 184 municípios, que aderiram ao Programa Nacional de Melhoria do Acesso e Qualidade da Atenção Básica. Avaliaram-se oito indicadores de avaliação clínica e sete de promoção da saúde, junto aos profissionais de saúde atuantes nas escolas. Resultados: os entrevistados eram enfermeiros (95,6\% e 98,3\%). Entre os ciclos, houve aumento da avaliação clínica (78,7\% e 91,3\%), promoção da saúde e prevenção de doenças (82,5\% e $89,3 \%)$, e levantamento de escolares para acompanhamento $(41,4 \%$ e $66,4 \%)$ nas escolas. Conclusões: ações de saúde na escola avançaram entre os ciclos, tendo o enfermeiro como protagonista na saúde escolar, o que pode reduzir vulnerabilidades em crianças e adolescentes e qualificar a Atenção Básica.

Descritores: Enfermagem; Promoção da Saúde; Prevenção de Doenças; Estratégia Saúde da Família, Promoção da Saúde Escolar.

\section{RESUMEN}

Objetivos comparar las acciones de promoción de la salud realizadas por los equipos de Salud de la Familia de Ceará vinculados al Programa Salud en la Escuela. Métodos: estudio transversal, que involucró el primer y segundo ciclo de evaluación externa de 910 y 1.626 equipos, respectivamente, de 184 municipios adheridos al Programa Nacional de Mejoramiento del Acceso y Calidad de la Atención Primaria. Se evaluaron ocho indicadores de evaluación clínica y siete indicadores de promoción de la salud con profesionales de la salud que trabajan en las escuelas. Resultados: los entrevistados fueron enfermeros ( $95,6 \%$ y $98,3 \%)$. Entre ciclos, hubo un aumento en la evaluación clínica ( $78,7 \%$ y 91,3\%), promoción de la salud y prevención de enfermedades $(82,5 \%$ y $89,3 \%)$, y encuesta a los estudiantes para el seguimiento $(41,4 \%$ y $66,4 \%)$ en las escuelas. Conclusiones: las acciones de salud en la escuela avanzaron entre ciclos, con la enfermera como protagonista en la salud escolar, que pueden reducir las vulnerabilidades en niños y adolescentes y calificar la Atención Primaria. Descriptores: Enfermería; Promoción de la Salud; Prevención de Enfermedades; Estrategia de Salud Familiar; Servicios de Salud Escolar. 


\section{INTRODUCTION}

Over the past decade, the World Health Organization has strengthened the Adolescent Friendly Health Services initiative, which aims to sensitize health services to adequately welcome adolescents, offering actions based on real needs and recommending public policy implementation and shared work between health units and the school space as part of successful strategies ${ }^{(1)}$.

Based on this premise, in Brazil, the School Health Program (PSE - Programa Saúde na Escola), an intersectoral policy developed by the Ministries of Health and Education, has worked on comprehensive training of students, through health promotion and disease prevention and health care actions for children, adolescents and young people, with a view to coping with the vulnerabilities of this period of life ${ }^{(2-3)}$.

This program is part of strategies aimed at achieving the Brazilian National Health Promotion Policy (PNPS - Política Nacional de Promoção da Saúde)(4-5), being one of the most prominent public policies for childhood and adolescence in Brazil( ${ }^{(6)}$, providing clinical assessment actions for students, health promotion and disease/grievance prevention and training of education, health and youth professionals. It is noteworthy that performing these activities must be planned and carried out by the Family Health team (FHt) and by school professionals ${ }^{(3)}$.

In addition to PSE, several policies have been implemented with the objective of achieving an effective, welcoming, resolutive and quality Primary Care in Brazil. To this end, in 2011, the Ministry of Health launched the Brazilian National Program for Improving Access and Quality of Primary Care (PMAQ-AB - Programa Nacional de Melhoria do Acesso e da Qualidade da Atenção Básica), seeking to facilitate users' access to health facilities and improve the quality of Primary Care (PC), through the institutionalization of ${ }^{(7)}$ assessment, including actions under PSE, throughout Brazil.

Internationally, health assessment, involving adolescence, has valued the context and sociocultural, economic and regional needs, especially in developing countries ${ }^{(8)}$. A study conducted in Sudan, a country on adolescent health policies, found weaknesses in action implementation, due to the attention of authorities to the specific context of each region ${ }^{(9)}$. In countries where adolescents experience contexts of greater conflict, either by violence or by the need for humanitarian aid, assessment of implemented programs indicates that these initiatives provide access to health, leisure and forms of income generation that would not occur otherwise. Therefore, investigations on analysis of program results and even economic viability are essential to break with inequities ${ }^{(10)}$.

Research aimed at analysis of actions carried out by $\mathrm{FHt}$, with regard to adolescent health promotion, either nationally or in northeastern Brazil, are still scarce, with most studies focused on developing actions in PSE at the local or municipal level ${ }^{(11-14)}$. Meanwhile, others assess a single action proposed by the program, such as actions to promote healthy eating or prevention of Sexually Transmitted Diseases (STD) ${ }^{(15-17)}$. These facts demonstrate a knowledge gap, requiring research on the subject.

It is noteworthy that northeastern Brazil presents considerable economic and social inequalities that contribute to the increase of health vulnerabilities in childhood and adolescence. Ceará State, for instance, has generally improved indicators related to violence, however, data on murders of adolescent and young girls deserve attention, with an increase of $13 \%$ in $2019^{(18)}$. Other findings can be highlighted, such as the high prevalence of adolescence pregnancy and high fertility rate in girls aged 15 to 19 years (62/1000) (18). Tied to this, high alcohol consumption among adolescents is pointed out (34.3\% made use in life; $22.2 \%$ in the last 12 months; and $8.8 \%$ in the last 30 days $)^{(19)}$. This outlook demonstrates the real need for studies with this portion of the population, seeking to outline intervention measures to modify reality.

For nursing, studies that deal with assessment of PSE actions, over time, encompassing the components of actions, are relevant and allow to know care practices, proposing more effective health actions at school and strengthening performance with actions that meet adolescents' needs comprehensively, contributing to PC consolidation in Brazil. In this context, no studies were observed that analyzed the secondary data of $\mathrm{PMAQ}-\mathrm{AB}$ regarding the health promotion actions carried out by FHt, in Ceará, Brazil. This finding was the main motivation for this study, since data from assessment programs are fundamental for analyzing the current situation, in order to support the design of new actions and the implementation of health decisions.

\section{OBJECTIVES}

To compare health promotion actions carried out by Family Health teams in Ceará, linked to the School Health Program.

\section{METHODS}

\section{Ethical aspects}

This research met the ethical precepts of the Resolution of the Brazilian National Health Council (Conselho Nacional de Saúde) and used only secondary data, from the public domain, available on the internet, without submission to a Research Ethics Committee with Human Beings.

\section{Study design, period and location}

This is a quantitative study composed of two cross-sectional surveys, corresponding to the external assessment of assessment cycles, based on data available in 2013 and 2015, from PMAQ-AB, in Ceará. Ceará is located in northeastern Brazil, with a population of about 9 million inhabitants, distributed in 184 municipalities ${ }^{(20)}$.

PMAQ is the largest Brazilian assessment implemented by the Ministry of Health, focusing on expanding access and improving quality standard. Similarly, in all services offered in PC, is divided into four phases, carried out over a period of approximately two years: compliance and contractualization ( $1^{\text {st }}$ phase); development ( $2^{\text {nd }}$ phase); external assessment ( $3^{\text {rd }}$ phase); recontractualization $\left(4^{\text {th }} \text { phase }\right)^{(7)}$.

In total, four modules are applied in PMAQ-AB assessment: Basic Health Unit observation (module I); interview with $\mathrm{FHt}$ professionals and document verification (module II); interview with users (module III); and verification of documents 
and information previously inserted in the electronic module (module IV). Information was obtained regarding module II application, carried out in the third phase of external assessment, in an interview with a FHt professional who performs activities at the school. External assessment was carried out by universities throughout Brazil that visited FHt, in order to assess on site performance in Family Health Strategy (FHS). The visit was previously scheduled with managers from the municipality and the health unit.

It is noteworthy that PMAQ presented a third cycle in 2017; however, it was decided not to include the results of this, since variables analyzed did not correspond to the same questions of the previous cycles, which, in fact, compromised the comparative analysis.

\section{Data source}

This study used as data source the microdata of PMAQ-AB External Assessment survey, present in the Ministry of Health portal (http://aps.saude.gov.br/ape/pmaq ), available online ${ }^{(21)}$.

\section{Population/sample; inclusion and exclusion criteria}

Thus, 2,536 FHt from all regions of Ceará participated in the study during the first and second cycles of PMAQ-AB. In the first cycle, $910 \mathrm{FHt}$ joined PMAQ-AB, equivalent to $47.3 \%$ of all $\mathrm{FHt}$. In the first cycle, $910 \mathrm{FHt}$ joined PMAQ-AB, equivalent to $47.3 \%$ of all FHt. In the second, 1,626 FHt joined PMAQ-AB, corresponding to $75 \%$ of the total. It is noteworthy that in the participating FHS, the inclusion criterion was to have requested external assessment during the first phase of the program's compliance and contractualization. For professionals, the criteria were having a degree in health, being a member of the assessed $\mathrm{FHt}$, having been appointed by the team, working in the school and having knowledge about the work process.

\section{Study protocol}

The information contained in module II related to health promotion actions developed by FHS was used to collect data. The instrument was elaborated by the Ministry of Health, with the following topics: (1) about professional performance, professional category and (2) performance of the FHt at school: survey of students in need of health care; carrying out clinical assessment actions, such as checking the vaccination schedule, early detection of hypertension, identifying neglected health conditions, ophthalmic, auditory, nutritional, and oral health assessment; promotion and prevention activities, such as education for reproductive and sexual health and prevention of STD/ Acquired Immunodeficiency Syndrome (AIDS), improvement of body practices and physical activity in schools, prevention of the use of alcohol, tobacco and other drugs, promotion and healthy food and nutrition education and training and debate with school professionals ${ }^{(6)}$.

The instrument was applied by an interviewer, previously trained in an appropriate place in the health unit, lasting about 60 to 90 minutes. For data collection purposes, only one FHS professional responded to the instrument, which was chosen by FHt itself.

\section{Analysis of results and statistics}

A descriptive analysis was used to present data, considering absolute and relative frequency of questions related to professional profile. The percentages and the respective $95 \%$ confidence intervals $(95 \% \mathrm{Cl})$ of $\mathrm{FHt}$ that reported actions in schools were estimated, considering the general questions about actions in school and those that specified the types of actions in the axes "clinical assessment" and "health promotion and disease prevention". The sum of actions reported by each FHt was computed for these two axes and for the total number of actions in schools. The differences between the two PMAQ-AB cycles were considered statistically significant, when there was no overlap of the respective $95 \% \mathrm{Cl}$. Analyses were performed through the statistical program Stata 14.0 (Stata Corp LP, United States).

\section{RESULTS}

Most professionals in both cycles were nurses, 870 (95.6\%) and 1,598 (98.3\%), respectively. Among the other categories, 24 (2.6\%) were physicians and participated in the first cycle and 20 (1.2\%) in the second. The other categories of health field totaled $16(1.8 \%)$ and $8(0.5 \%)$, respectively.

Regarding length of experience in $\mathrm{FHt}$, in both cycles, the average was $51.5 \%$ (between one and five years), and in less than a year there were 232 (25.5\%) and 484 (29.8\%). Among those with more than 11 years in $\mathrm{FHt}, 64$ (7.0\%) and 59 (3.6\%) had such experience. Therefore, 798 (87.7\%) and 1,412 (86.8\%) professionals, in both cycles, participated or were in the process of complementary training in the area such as graduate studies.

The percentage of the FHS who reported performing actions at school (total) went from $85.2 \%$ to $92.9 \%$, and in the clinical assessment, there was an increase from $78.7 \%$ to $91.3 \%$, while the proportion that performed actions to promote health and disease prevention increased from $82.5 \%$ to $89.3 \%$. FHS who mentioned having a survey of schoolchildren who needed clinical monitoring increased from $41.4 \%$ to $66.4 \%$.

In both cycles, the most reported clinical assessments were updating the vaccination schedule (64.2\% and $87.6 \%)$, nutritional assessment (56.9\% and $81.4 \%)$, oral health assessment $(55.8 \%$ and $75.6 \%$ ) and early detection of systemic arterial hypertension (44.0\% and 66.2\%). More significant increases in ophthalmological assessment actions (from $21.8 \%$ to $71.6 \%$ ), detection of neglected health problems (from $30.8 \%$ to $86.4 \%$ ) and hearing assessment (from $17.0 \%$ ) stand out $\%$ to $41.6 \%$ ) (Table 1 ).

As for health promotion and disease prevention actions, there was a significant increase between cycles. The most reported health promotion and disease prevention actions were education for reproductive, sexual health and STD/AIDS prevention ( $66.5 \%$ and $84.3 \%$, respectively), education and healthy food and nutrition promotion actions (64.6\% and $79.3 \%)$ and prevention of use of alcohol, tobacco, and other drugs (49.1\% and $69.1 \%$ ). More significant increases are pointed out for training actions of education professionals to work with health education (from $24.8 \%$ to $47.9 \%$ ), debate with school teachers (from $32.5 \%$ to $56.8 \%$ ) and bodily and physical activity promotion (from $35.4 \%$ to $59.2 \%$ ) (Table 2). 
In clinical assessment actions, the FHS proportion, which mentioned performing most of the actions assessed in PMAQ-AB (from five to seven actions) increased by more than $100 \%$, with reductions in the proportion of those that had other amounts of clinical assessment actions. An increase of $95.8 \%$ was observed in the proportion of $\mathrm{FHt}$ who reported performing five to six actions to promote health and disease prevention. When considering the total number of actions, the proportion of those who mentioned seven or more health actions at school increased $69.8 \%$. This fact was allied to the reduction in the proportion of those who had less actions (none, 1-2 actions, 3-4 actions and 5-6 actions) (Table 3).

\section{DISCUSSION}

The study revealed that the professionals who answered the most assessment questions were nurses, demonstrating their great insertion in $\mathrm{FHt}$ and in actions aimed at health promotion at school. The work developed by nurses has promoted healthier habits and lifestyles, in addition to modifying the social and environmental conditions of the territory ${ }^{(22)}$. Studies confirm the expressive performance of these professionals in health promotion actions at school, standing out as protagonists in PSE implementation, despite the difficulties ${ }^{(23-24)}$.

Table 1 - Percentage of professionals from family health teams who reported different types of clinical assessment actions in schools in Ceará, Fortaleza, Ceará, Brazil, 2015

\begin{tabular}{|c|c|c|c|c|}
\hline \multirow{2}{*}{ Variables } & \multicolumn{2}{|c|}{$1^{\text {st }}$ Cycle } & \multicolumn{2}{|c|}{$2^{\text {nd }}$ Cycle } \\
\hline & $(\%)$ & $95 \% \mathrm{Cl}$ & (\%) & $95 \% \mathrm{Cl}$ \\
\hline Vaccine calendar update & 64.2 & $61.0-67.2$ & 87.6 & $85.9-89.2$ \\
\hline Early detection of systolic hypertension & 44.0 & $40.8-47.2$ & 66.2 & $63.9-68.5$ \\
\hline Detection of neglected health problems & 30.8 & $27.8-33.9$ & 86.4 & $84.7-88.0$ \\
\hline Ophthalmologic assessment & 21.8 & $19.2-24.6$ & 71.6 & $69.3-73.7$ \\
\hline Hearing assessment & 17.0 & $14.7-19.6$ & 41.6 & $39.2-44.0$ \\
\hline Nutritional assessment & 56.9 & $53.7-60.1$ & 81.4 & $79.4-83.2$ \\
\hline Oral health assessment & 55.8 & $52.6-59.0$ & 75.6 & $73.5-77.7$ \\
\hline Others & 0.8 & $0.3-1.6$ & 31.5 & $29.3-33.9$ \\
\hline
\end{tabular}

Source: Brazilian National Program to Improve Access and Quality of Primary Care, data published in 2013 and 2015.

Note: $\mathrm{Cl}$ - Confidence Interval.

Table 2 - Percentage of professionals from family health teams who reported different types of health promotion and disease prevention actions in schools in Ceará, Fortaleza, Ceará, Brazil, 2015

\begin{tabular}{|c|c|c|c|c|}
\hline \multirow{2}{*}{ Variables } & \multicolumn{2}{|c|}{$1^{\text {st }}$ Cycle } & \multicolumn{2}{|c|}{$2^{\text {nd }}$ Cycle } \\
\hline & (\%) & $95 \% \mathrm{Cl}$ & (\%) & $95 \% \mathrm{Cl}$ \\
\hline Food safety and healthy eating promotion & 64.6 & $61.4-67.7$ & 79.3 & $77.2-81.2$ \\
\hline Bodily and physical activity promotion & 35.4 & $32.3-38.6$ & 59.2 & $56.8-61.5$ \\
\hline $\begin{array}{l}\text { Education for sexual, reproductive health and prevention of Sexually Transmitted } \\
\text { Diseases/Acguired Immunodeficiency Syndrome }\end{array}$ & 66.5 & $63.3-69.5$ & 84.3 & $82.4-85.9$ \\
\hline Alcohol, tobacco and other drug use prevention & 49.1 & $45.9-52.4$ & 69.1 & $66.8-71.3$ \\
\hline Training of professionals to work with health education & 24.8 & $22.1-27.8$ & 47.9 & $45.5-50.3$ \\
\hline Debate with teachers & 32.5 & $29.6-35.6$ & 56.8 & $54.4-59.2$ \\
\hline Others & 2.6 & $1.7-3.9$ & 19.6 & $17.8-21.6$ \\
\hline
\end{tabular}

Source: Brazilian National Program to Improve Access and Quality of Primary Care, data published in 2013 and 2015.

Note: $\mathrm{Cl}$ - Confidence Interval.

Table 3 - Percentage of professionals from family health teams who reported health practices in schools in Ceará, according to amounts of actions, Fortaleza, Ceará, Brazil, 2015

\begin{tabular}{|c|c|c|c|}
\hline Variables & $\begin{array}{c}1^{\text {st }} \text { Cycle } \\
\%(95 \% \mathrm{Cl}) /\end{array}$ & $\begin{array}{c}2^{\text {nd }} \text { Cycle } \\
\%(95 \% \mathrm{Cl}) /\end{array}$ & Delta \%* \\
\hline \multicolumn{4}{|c|}{ Clinical assessment actions } \\
\hline None & $9.7(9.6-10.6)$ & $1.9(1.3-2.7)$ & -80.2 \\
\hline $1-2$ & $27.7(24.7-31.0)$ & $5.4(4.3-6.6)$ & -80.7 \\
\hline $3-4$ & $29.4(26.3-32.7)$ & $12.4(10.8-14.1)$ & -57.9 \\
\hline $5-6$ & $21.7(18.9-24.7)$ & $48.4(45.9-50.9)$ & 123.2 \\
\hline 7 & $11.5(9.4-13.9)$ & $32.0(29.6-34.4)$ & 178.4 \\
\hline \multicolumn{4}{|c|}{ Health promotion and prevention actions } \\
\hline None & $9.0(7.2-11.3)$ & $3.8(2.9-4.8)$ & -57.9 \\
\hline $1-2$ & $26.5(23.4-29.7)$ & $13.3(11.7-15.1)$ & -49.7 \\
\hline $3-4$ & $37.3(33.9-40.8)$ & $29.6(27.3-31.9)$ & -20.6 \\
\hline $5-6$ & $27.2(24.2-30.5)$ & $53.3(50.8-55.8)$ & 95.8 \\
\hline \multicolumn{4}{|c|}{ Combined actions } \\
\hline None & $2.7(1.8-4.1)$ & $0.9(0.5-1.5)$ & -65.8 \\
\hline $1-2$ & $11.9(9.8-14.3)$ & $2.3(1.6-3.1)$ & -81.0 \\
\hline $3-4$ & $16.1(13.7-18.9)$ & $3.4(2.6-4.4)$ & -78.7 \\
\hline $5-6$ & $18.5(15.9-21.3)$ & $7.1(5.9-8.4)$ & -61.6 \\
\hline$\geq 7$ & $50.8(47.3-54.4)$ & $86.3(84.4-87.9)$ & 69.8 \\
\hline
\end{tabular}

Source: Brazilian National Program to Improve Access and Quality of Primary Care, data published in 2013 and 2015.

Note: $\mathrm{Cl}$ - Confidence Interval; *Delta \%: percentage difference between cycles. 
With regard to complementary training in the field, most had recently joined $\mathrm{FHt}$ and were in the process of complementary training. A study conducted with FHS nurses of a municipality in Minas Gerais, Brazil, identified similar professional profiles, since $40 \%$ had less than one year of work in $\mathrm{FHt}, 56.6 \%$ up to five years and $80 \%$ had graduate studies of the specialization type and in the area of Family Health ${ }^{(25)}$.

This situation can be explained by the expansion of FHS coverage in Brazil, resulting in the increase in FHt and also of nurses, opening up a field of work for young professionals. In addition, nurses' concern about academic education and investment is increasingly frequent in graduate courses ${ }^{(26)}$.

There was an increase in activities performed by $\mathrm{FHt}$, based on the actions recommended by PSE (clinical assessment of students and actions to promote health and prevention of diseases and grievances). This is due to the importance attributed by the municipalities, improving the planning of actions and articulating more with schools, in order to identify the real health problems, favoring the access of the student in the health network, if necessary ${ }^{(27)}$.

In particular, PSE clinical assessment, performed by $\mathrm{FHt}$, had an increase in all indicators, with emphasis on ophthalmological assessment, detection of neglected health problems and auditory assessment ${ }^{(28-29)}$. However, it is emphasized the need to expand access to auditory assessments in the work process of $P C$, since less than $50 \%$ of $\mathrm{FHt}$ offer this type of service in schools.

Nevertheless, a study conducted with elementary and high school students from Bauru-SP, Brazil, showed that a large majority made headphone use, of which $60.3 \%$ reported at least one hearing complaint, awakening to the importance of carrying out systematic actions aimed at preventing hearing loss in the young population ${ }^{(30)}$.

Concerning ophthalmological assessment, this action has been performed frequently by $\mathrm{FHt}$. A research carried out with students between five and 17 years of public education in Barcelos, AM, Brazil, observed a visual deficit in $6.3 \%$ of participants and recommended reinforcing the development of actions aimed at the prevention of visual problems and timely treatment for this population ${ }^{(31)}$.

An important point developed by $\mathrm{FHt}$ is the detection of neglected diseases or illnesses. Since 2011, Brazil has been launching investments to eliminate such diseases, as provided for in a national plan aimed at integrating actions against leprosy, onchocerciasis, filariasis, trachoma, schistosomiasis and geohelminthiasis. However, the goals between 2011 and 2015 have been revised due to the difficulty in reaching them ${ }^{(32)}$.

Nurses, as FHt members, collaborate effectively in the early detection and care promotion in the area. A study conducted in the Cariri region of Ceará, an endemic area for tuberculosis and leprosy, presents nursing actions aimed at the early detection of these diseases, such as active search for new cases, directly observed treatment, health education and comprehensive care for assisted people ${ }^{(33)}$.

With regard to the component of health promotion and disease/grievance prevention, the development of different types of actions was evidenced, as proposed by PSE. It proposes that this is an educational moment to work on important themes for adolescents through participatory and active learning methodologies, ensuring the possibility for them to know and make more positive choices for health and favoring students' role for self-care ${ }^{(27)}$.

This component of health promotion/disease prevention includes education actions for reproductive and sexual health and STD/AIDS prevention, training and debate of school professionals, healthy food and nutrition education and promotion, prevention of alcohol, tobacco use and other drugs and physical and bodily activity practices ${ }^{(28-29)}$. Many of these actions are part of the initiatives proposed by PNPS that advocates investment in health promotion actions in priority topics, such as: promoting adequate and healthy food; the promotion of physical and bodily activities; training and continuing education of professionals; coping with the abusive use of alcohol, tobacco, derivatives and other drugs $s^{(5)}$.

Thus, the present study revealed that, in the comparison of cycles, there was an increase in actions in the thematic areas recommended for this component, being the highest increases observed for actions to promote bodily practices and physical activities, training of education professionals to work with health education and debate with school teachers.

Insufficient physical activity is one of the leading causes of morbidity and mortality worldwide, contributing significantly to the strong incidence and severity of a vast number of chronic non-communicable diseases in the population ${ }^{(34)}$. National and international surveys show that insufficient physical activity has been high in the young population of several countries, making PC and its performance in the school an important strategy to promote this health behavior in children and adolescents ${ }^{(35-37)}$. Bodily practices/physical activities by adolescents bring numerous benefits, contributing to the improvement of sleep, strength, mood, social interaction, making it possible to experience, reflect and reconstruct senses and meanings about body, corporeality, gender and leadership in their relationship with the world ${ }^{(38)}$.

A study conducted in state schools in Natal, RN, Brazil, describes the success of a nursing care program for adolescents, directed to the prevention and control of overweight and obesity, highlighting the need to make physical exercises available in the school environment, since, in participating schools, such practice was not performed ${ }^{(39)}$. Moreover, the school context has been recognized as a relevant space for actions aimed at health promotion and disease prevention, such as obesity, including in countries and contexts of social vulnerability ${ }^{(40)}$.

The remarkable increase in actions in PSE, found in the present study, demonstrates FHS engagement and effort in promoting actions that aim to encourage in adolescents the search for a lifestyle with more quality, encouraging daily physical/body activity practice by this group, thus contributing to improve this population's health and quality of life.

In addition to actions with students, the processes of continuing education observed and debates with school teachers contribute to train the education and health teams working at PSE ${ }^{(3)}$, being identified, in this study, a considerable increase of these actions. This process is part of the specific objectives and guidelines of PNPS to encourage the improvement of collective and individual skills and to support the ongoing training and qualification of 
managers, workers and citizens in health promotion, strategies capable of overcoming the challenge of fragmentation of actions.

\section{Study limitations}

This study has as limitations the statewide scope of the research, carried out in a single region of Brazil, which does not allow extrapolation of the findings to other Brazilian contexts. Moreover, the low adherence to PMAQ-AB in FHt, especially in the first cycle, may have influenced the real estimates of actions in PSE, in that period, and in the comparisons between the two surveys. However, it is believed that due to similarities presented between $\mathrm{FHt}$ in the two assessment moments similarity was obtained in the samples and in the comparative potential. Furthermore, as PSE issues were excluded from PMAQ-AB in the third cycle (in 2017), carrying out trend analysis of these indicators was impossible.

\section{Contributions to nursing, health, and public policies}

This research is one of the first studies to present trend, over the years, in performance of actions carried out by FHS participating in PSE, nationally based on PNPS, using data from the largest PC assessment survey in the country, PMAQ-AB.

The results showed that nurses have been protagonists in health actions at school, highlighting the expansion of actions that seek to improve students' health and quality of life and reduce vulnerabilities, with actions aimed at health promotion, prevention and care. It also presents potential performance and commitment of these professionals to PMAQ-AB, thus contributing for continuous improvement of quality and access to health services offered by PC in northeastern Brazil.

The research also showed the importance of health assessment processes, still incipient in Brazil, for the knowledge of concrete results in the field, decision-making and construction and strengthening of public policies that consider the school population's real needs, providing an increase in efficiency and effectiveness of activities developed in the field.

\section{CONCLUSIONS}

In conclusion, the results showed an increase in activities performed in PSE, between the first and second cycle of PMAQ$A B$, both in clinical assessment and in health promotion/disease prevention. Nevertheless, it was observed that nurses as an important part of $\mathrm{FHt}$, which performs actions at school and seeks PC improvement and qualification.

Therefore, it is necessary to ensure these advances in PC and that PC interlocution with the school context is preserved and expanded. To this end, it is urgent to strengthen clinical assessment, health promotion and disease prevention actions to meet the health needs and vulnerabilities of young population attending school, in order to collaborate with the development of children, adolescents and young people assisted, positively impacting their quality of life and contributing, in the near future, to changes in the outlook of health conditions so worrying that affect the Brazilian population, especially among the poorest states.

\section{REFERENCES}

1. Hoopes AJ, Agarwal P, Bull S, Sheana Bull, Venkatraman CM. Measuring adolescent friendly health services in India: a scoping review of evaluations. Reprod Health. 2016);13(137). doi: 10.1186/s12978-016-0251-8

2. Pinto MB, Silva KL. Promoção da saúde na escola: discursos, representações e abordagens. Rev Bras Enferm. 2020;73(3):e20180774. doi: 10.1590/0034-7167-2018-0774

3. Ministério da Saúde (BR). Caderno do gestor do PSE [Internet]. 2015 [cited 2020 Jun 20]. Available from: http://bvsms.saude.gov.br/bvs/ publicacoes/caderno_gestor_pse.pdf

4. Dias MSA, Oliveira IP, Silva LMS, Vasconcelos MIO, Machado MFAS, Forte FDS, et al. The National Health Promotion Policy: an evaluability assessment in a health region in Brazil. Ciênc Saúde Coletiva. 2018;23(1):103-14. doi: 10.1590/1413-81232018231.24682015

5. Ministério da Saúde (BR). Secretaria de Vigilância em Saúde. Secretaria de Atenção à Saúde. Política Nacional de Promoção da Saúde: PNPS: revisão da Portaria MS/GM n 687, de 30 de março de 2006 [Internet]. Brasília: Ministério da Saúde; 2015[cited 2020 Jun 20]. 36p. Available from: http://bvsms.saude.gov.br/bvs/publicacoes/pnps_revisao_portaria_687.pdf

6. Machado MFAS, Gubert FA, Meyer APGFV, Sampaio YPCC, Dias MAS, Almeida AMB, et al. The health school programm: a health promotion strategy in primary care in Brazil. J Hum Growth Dev. 2015;25(3):307-12. doi: 10.7322/jhgd.96709

7. Flôres GMS, Weigelt LD, Rezende MS, Telles R, Krug SBF. [Public management at the SUS: considerations on the PMAQ-AB]. Saúde Debate. 2018;42(116):237-47. doi: 10.1590/0103-1104201811619 Portuguese

8. Chandra-Mouli V, Chatterjee S, Bose K. Do efforts to standardize, assess and improve the quality of health service provision to adolescents by government-run health services in low and middle income countries, lead to improvements in service-quality and service-utilization by adolescents? Reprod Health. 2016;13:10. doi: 10.1186/s12978-015-0111-y

9. Belaid L, Bayo P, Kamau L, Nakimuli E, Omoro E, Lobor R, et al. Health policy mapping and system gaps impeding the implementation of reproductive, maternal, neonatal, child, and adolescent health programs in South Sudan: a scoping review. Confl Health. 2020;14:20. doi: 10.1186/s13031-020-00258-0

10. Glass N, Remy MM, Mayo-Wilson LJ. Comparative effectiveness of an economic empowerment program on adolescent economic assets, education and health in a humanitarian setting. BMC Public Health. 2020;20(1):170. doi: 10.1186/s12889-020-8219- 
11. Brasil EGM, Silva RM, Silva MRF, Rodrigues DP, Queiroz MVO. Adolescent health promotion and the School Health Program: complexity in the articulation of health and education. Rev Esc Enferm USP. 2017;51:e03276. doi: 10.1590/s1980-220×2016039303276

12. Machado WD, Oliveira KMCP, Cunha CG, Araújo Jr DG, Silvino RHS, Dias MSA. [School health program": a look at the evaluation of components]. Sanare [Internet]. 2016 [cited 2019 Oct 22];15(1):62-8. Available from: https://sanare.emnuvens.com.br/sanare/article/ view/929/558 Portuguese.

13. Farias ICV, Sá RMPF, Figueiredo N, Menezes Filho A. [Cross-sectorial analysis in the health at schools program]. Rev Bras Educ Med. 2016;40(2):261-7. doi: 10.1590/1981-52712015v40n2e02642014 Portuguese.

14. Santiago LM, Rodrigues MTP, Oliveira Jr AD, Moreira TMM. [School Health Program implementation in Fortaleza-CE: performance of the Family Health Strategy staff]. Rev Bras Enferm. 2012;65(6):1026-9. doi: 10.1590/S0034-71672012000600020 Portuguese.

15. Bezerra MA, Carvalho EF, Oliveira JS, Leal VS. Health and nutrition in public and private schools in the city of Recife. Rev Bras Saude Mater Infant. 2017;17(1):191-200. doi: 10.1590/1806-930420170001000011

16. Dias MAS, Vieira FMBR, Silva LCC, Vasconcelos MIO, Machado MFAS. Inter-professional collaboration in the 'Health and Prevention in Schools' Project. Ciênc Saúde Coletiva. 2016;21(6):1789-98. doi: 10.1590/1413-81232015216.08112016

17. Souza NP, Lira PIC, Andrade LASS, Cabral PC, Carvalho AL, Oliveira JS. [The School Health Program and actions of food and nutrition: an exploratory analysis]. Rev APS [Internet]. 2015 [cited 2019 Oct 22];18(3):360-7. Available from: https://periodicos.ufff.br/index.php/aps/ article/view/15555 Portuguese.

18. Lins AL, Moura R, Barreira C (coord.). Centro de Estudos de Segurança e Cidadania. Rede de Observatórios da Segurança. Ceará: Denúncias de tortura nas prisões, ataque nas ruas, homicídios em queda. In: Retratos da Violência: cinco meses de monitoramento, análises e descobertas (junho a outubro de 2019). Rio de Janeiro: Centro de Estudos de Segurança e Cidadania; 2019. p.20-24.

19. Fundação Oswaldo Cruz. III Levantamento Nacional sobre o uso de Drogas pela População Brasileira - III LNUD [Internet]. Rio de Janeiro: Fiocruz, 2017 [cited 2020 May 18]. 528p. Available from: https://www.arca.fiocruz.br/handle/icict/34614

20. Brasil. Ministério da Economia. Fundação Instituto Brasileiro de Geografia e Estatística. Resolução n. ${ }^{\circ}$ 3, de 26 de agosto de 2019 . Divulga as estimativas da População para Estados e Municípios com data de referência em $1{ }^{\circ}$ de julho de 2019 [Internet]. Diário Oficial da União 28 Ago, 2019 [cited 2020 May 18]; Seção 1; n 166. Available from: http://pesquisa.in.gov.br/imprensa/jsp/visualiza/index.jsp?data=28/08/2019 \&jornal $=515 \&$ pagina $=374 \&$ totalArquivos $=485$

21. Ministério da Saúde (BR). Programa de Melhoria do Acesso e da Qualidade da Atenção Básica - PMAQ. Ciclos do PMAQ AB [Internet]. 2015[cited 2020 May 18]. Available from: http://aps.saude.gov.br/ape/pmaq

22. Mori FMLV, Edquen SB, Espinoza ZEL, Salazara RS. Competencies of the nurse in educational institutions: a look from educational managers. Rev Gaúcha Enferm. 2018;39:e2017-0152. doi: 10.1590/1983-1447.2018.2017-0152

23. Baggio MA, Berres R, Gregolin BPS, Aikes S. Introduction of the School Health Program in the city of Cascavel, Paraná State: report of nurses. Rev Bras Enferm. 2018;71(supl 4):1631-38. doi: 10.1590/0034-7167-2017-0188

24. Silva JR, Silva QAD, Menegon VGS. [The role of nursing in the school health program: the challenge of networking]. Rev Eletr Acervo Saúde [Internet]. 2017 [cited 2019 Oct 22];6(supl):461-8. Available from: https://www.acervosaude.com.br/doc/REAS12.pdf Portuguese.

25. Firmino AA, Moraes MC, Nascimento PEA, Paiva SMA, Silveira CA. action of nurses from the family health strategyin a city of Minas Gerais. Rev Saúde (Santa Maria). 2016;42(1):49-58. doi: 10.5902/2236583418694 Portuguese.

26. Faria MGA, Acioli S, Gallasch CH. [Profile of fluminense nurses of family health strategy participants of specialization course]. Enferm Foco [Internet]. 2016 [cited 2019 Oct 23];7(1):52-5. Available from: http://revista.cofen.gov.br/index.php/enfermagem/article/view/667 Portuguese.

27. Ministério da Saúde (BR). Manual instrutivo Programa Saúde na Escola. Brasília: Ministério da Saúde; 2013.

28. Ministério da Saúde (BR). Secretaria de Atenção à Saúde. Departamento de Atenção Básica. Programa Nacional de Melhoria do Acesso e da Qualidade da Atenção Básica (PMAQ): manual instrutivo para as equipes de atenção básica e NASF. Brasília: Ministério da Saúde; 2017.

29. Ministério da Saúde (BR). Secretaria de Atenção à Saúde. Departamento de Atenção Básica. Instrumento de Avaliação Externa para as Equipes de Atenção Básica, Saúde Bucal e NASF (Saúde da Família ou Parametrizada). Brasília: Ministério da Saúde;2017.

30. Santana BA, Alvarenga KF, Cruz PC, Quadros IA, Jacob-Corteletti LCB. Prevention in a school environment of hearing loss due to leisure noise. Audiol Commun Res. 2016;21:e1641. doi: 10.1590/2317-6431-2015-1641

31. Régis-Aranha LA, Moraes FH, Santos STC, Heufemann NEC, Magalhães WOG, Zacarias FRP, et al. Visual acuity and academic performance of students in a Brazilian Amazon municipality. Esc Anna Nery. 2017;21(2):e20170032. doi: 10.5935/1414-8145.20170032

32. Ministério da Saúde (BR). Secretaria de Vigilância em Saúde. Boletim Epidemiológico. Situação epidemiológica e estratégias de prevenção, controle e eliminação das doenças tropicais negligenciadas no Brasil, 1995 a 2016. Brasília: Ministério da Saúde; 2018.

33. Silva IGB, Lima Filho FJR, Lopes MSV, Cavalcante EGR, Lima GS, Alves HLC, et al. [Academic league of neglected diseases: shortening ties between teaching, service and management]. Rev Saúde Ciênc[Internet]. 2017 [cited 2019 Oct 23];6(3):22-30. Available from: http://www. ufcg.edu.br/revistasaudeeciencia/index.php/RSC-UFCG/article/view/477/303

34. Programa das Nações Unidas para o Desenvolvimento (PNUD). Relatório de Desenvolvimento Humano Nacional - Movimento é Vida: Atividades Físicas e Esportivas para Todas as Pessoas: 2017 [Internet]. Brasília: PNUD; 2017[cited 2019 Oct 23]. Availabe from: http:// movimentoevida.org/wp-content/uploads/2017/09/PNUD_RNDH_completo.pdf 
35. Ferreira RW, Varela AR, Monteiro LZ, Häfele CA, Santos SJ, Wendt A, et al. Desigualdades sociodemográficas na prática de atividade física de lazer e deslocamento ativo para a escola em adolescentes: Pesquisa Nacional de Saúde do Escolar (PeNSE 2009, 2012 e 2015). Cad Saúde Pública [Internet]. 2018 [cited 2020 Jun 20];34(4). Available from: scielo.org/article/csp/2018.v34n4/e00037917/

36. Santos-Labrador Ricardo M. Medición mediante acelerometría de los niveles de actividad física de una muestra de adolescentes españoles. Rev Salud Pública. 2019;21(5):e176666. doi: 10.15446/rsap.v21n5.76666

37. Christofaro DGD, Fernandes RA, Martins C, Ronque VER, Coelho-e-Silva MJ, Silva AM, et al. Prevalence of physical activity through the practice of sports among adolescents from Portuguese speaking countries. Ciên Saúde Coletiva. 20(4):1199-206:2015. doi: 10.1590/1413-81232015204.00692014

38. World Health Organization (WHO). Global Recommendations on Physical Activity for Health [Internet]. Geneva: OMS; 2010 [cited 2020 Jun 18]. Available from: https://apps.who.int/iris/bitstream/handle/10665/44399/9789241599979_eng.pdf?sequence=1

39. Vieira CENK, Dantas DNA, Miranda LSMV, Araújo AKC, Monteiro Al, Enders BC. School Health Nursing Program: prevention and control of overweight/obesity in adolescents. Rev Esc Enferm USP. 2018;52:e03339. doi: 10.1590/s1980-220×2017025403339

40. Guerra PH, Silveira JAC, Salvador EP. Physical activity and nutrition education at the school environment aimed at preventing childhood obesity: evidence from systematic reviews. J Pediatr [Internet]. 2016 [cited 2020 Jun 20];92(1):15-23. Available from: http://sciencedirect. com/science/article/pii/S2255553615001433 